\title{
The effect of production system and management practices on the quality of meat products from ruminant livestock
}

\author{
E.C. Webb ${ }^{\#}$ \& L.J. Erasmus \\ Department of Animal and Wildlife Sciences, University of Pretoria, Pretoria 0002, South Africa \\ Associates of the Institute of Food, Nutrition and Well-being, University of Pretoria, Pretoria 0002, South Africa
}

\author{
Copyright resides with the authors in terms of the Creative Commons Attribution 2.5 South African Licence. \\ See: http://creativecommons.org/licenses/by/2.5/za \\ Condition of use: The user may copy, distribute, transmit and adapt the work, but must recognise the authors and the South African Journal \\ of Animal Science.
}

\begin{abstract}
Demands for products of animal origin are increasing worldwide owing to the significant growth in the human population and changes in the health, wealth and life expectancy of people. The agricultural sector has the scientific knowledge, expertise and technology to respond to these challenges, but consumers are concerned about the methods used to meet these new challenges. They are also concerned about the environmental impact of modern technologies and intensification of production systems. Various combinations of pasture-based and intensive systems are employed to raise ruminant livestock, depending on resources and climate. The quality of animal products from production systems differs, but there are advantages and disadvantages for each. In South Africa, cattle and sheep are generally fattened for short periods to ensure efficient production and to meet market requirements. This is more easily achieved by feeding different proportions of concentrate diets, with or without feed additives and growth promotants that are approved for use in food-producing animals. Hormonal growth implants are strictly regulated for use in animal production systems. Production systems affect both the extrinsic and intrinsic aspects of carcass and meat quality of livestock. Extrinsic aspects that are affected include weight gain, age at slaughter and carcass weight. Concentrate feeding generally yields a more consistent carcass composition than pasture-fed animals, which addresses the necessity for more consistent meat quality. Intrinsic aspects of animal products that are affected include carcass composition and conformation, carcass fat content and colour, meat composition, colour, tenderness and flavour. Beef and lamb from pastures are darker, and carcass fat contains more yellow pigments, which may affect a consumer's choice to purchase. The typical pasture flavour in meat is because of the presence of branched-chain fatty acids, 3-methylindole and other oxidation products, and off-flavours are often detected. In many countries, the meat flavour of intensively fed livestock is preferred to pasture-fed animals, but certain consumers prefer the more intense pasture flavour. Pasture feeding has beneficial effects on n-3 fatty acids, notably eicosapentaenoic acid (EPA, C20:5n-3) and docasahexaenoic acid (DHA, C22:6n-3). Beef and lamb from pasture-fed animals are generally less tender, but shelf life is better, owing to the presence of antioxidants such as vitamin E.
\end{abstract}

Keywords: Hormonal growth implants, feed additives, antimicrobial implants, carcass quality, meat quality \#Corresponding author: Edward.webb@up.ac.za

\section{Introduction}

The demand for products of animal origin is increasing worldwide, owing to the significant growth in the human population (Roughgarden, 1979) and changes in the health, wealth and life expectancy of people. There is a similar increase in demand for good-quality protein from animal products in developing countries (Webb, 2013), where large numbers of people suffer from hunger and starvation, while problems associated with malnutrition, obesity and the metabolic syndrome are on the rise. It is estimated that global livestock production has to double by 2050 to satisfy the rising demands for animal products (Ilea, 2009). Most of this growth is expected to occur in developing countries, which are often poverty ridden and faced with civil wars or poor governance. 
Increasing demands for agricultural products became a reality during the Industrial Revolution from about 1760 to 1820 , which involved the adoption of new manufacturing practices. The agricultural sector was fast to respond to the challenges of this crossroad in human history by increasing the volumes of agricultural produce. Much of the increased agricultural production was achieved by using coal rather than wood or other biofuels, and shifting to steam power, machines and modern tools. This period of human history represents an era of unprecedented sustained economic growth, which increased the quality of life of ordinary people worldwide. The rapid growth in demand for agricultural products resulted in the 'livestock revolution' (Delgado et al., 1999), which changed the face of agriculture irrevocably in order to support increasing per capita economic growth and social development of a rapidly changing human population (Steinfeld, 2004; Pica-Ciamarra \& Otte, 2009).

Unfortunately, human populations on the various continents are dissimilar in terms of population dynamics, per capita consumption and utilization of natural resources (UN, 2004). For example, in developing countries, social and environmental responsibilities are addressed as national priorities, but many developing countries are still trying to cope with the burdens of food security and access to clean water (Webb \& Casey, 2010). It follows that developed countries will continue to produce more in order to supply the demand for food in developing countries. Much of the rising demand in food is met through intensification of agricultural production systems, but with rising concern about the environmental impact (Steinfeld et al., 2006).

This explains in part why consumers question the methods used to increase agricultural production and the associated social and environmental impact of production systems (Frazer, 2005). In animal agriculture, significant progress has been made in terms of breeding, feeding and management of livestock in different production systems in order to increase the level and efficiency of animal production (Webb \& Casey, 2010). Improvements in yields and production efficiency arose from a better understanding and exploitation of the science of animal production and by applying appropriate technologies. Intensification of animal agriculture occurred along one of two ways, namely horizontal or vertical integration (Webb, 2013). Horizontal integration is based on the conversion of natural areas (including conservation areas and forests) into agricultural land for livestock grazing, while the approach in vertical integration is to increase the efficiency of production, and link the subsystems in the production cycle in a more efficient way without necessarily utilizing more land or natural resources (Webb, 2013). The purpose of this paper is to provide a perspective of the effects of animal production systems on the quality and safety of animal products for human consumption.

\section{The changing agricultural landscape}

A key characteristic of the livestock industry after the Industrial Revolution was increasing livestock numbers, followed by maximum yield, which is also characteristic of livestock industries in many developing countries (Steinfeld, 2004). An interesting feature of production systems in developing countries is that there is generally a greater increase in numbers than productivity. According to Steinfeld (2004), livestock production in developed countries are highly efficient owing to the limited availability of agricultural land, which is better utilized, and much more attention is given to animal ethics, environmental impact, product quality, traceability and consumer satisfaction.

The growth and efficiency of livestock have been improved tremendously through the adoption of scientific methodologies (Green et al., 2007). Worldwide poultry and pig production systems are now mostly intensive, but the effects of production systems on the quality of products from these species fall beyond the scope of this review. In South Africa, cattle and sheep are still kept mostly on extensive grazing or pasture in various production systems. In a recent review on the effects of genetic selection for growth and efficiency in livestock, Webb \& Casey (2010) showed that the use of scientific methods of feeding and breeding has yielded remarkable results in growth and efficiency of livestock in both intensive and extensive production systems.

Unfortunately, improvements in livestock production are often seen as an endless process to increase yields, gains and efficiencies. On the contrary, livestock scientists have a good grasp of the physiological limitations of animals, and the environmental impact of production systems, and they make a concerted effort to better synchronize species, breeds and production systems in different environments and produce products that are safe and meet consumer demands (Webb \& Casey, 2010). 


\section{Production systems}

Different production systems are used to raise and fatten ruminant livestock for food production. In North America, the popular categories include conventional feeding and natural or organic feeding systems and this is similar in most developed countries. Conventional feeding systems use different combinations of pasture or extensive grazing, and intensive fattening with concentrates that may include different raw materials, feed additives, antimicrobials and hormonal growth implants. In North America and Western Europe, cow-calf production systems are often intensive. Natural and organic feeding systems differ somewhat, but both are usually based on planted pastures or extensive grazing (sometimes referred to as grazing or grass-fed systems) with minimal or no feed supplements and usually no hormonal growth implants (Wileman et al., 2009).

Grass feeding normally results in slower growth rates because hormonal growth implants and concentrate feeds are not generally used, and feed supplements are limited to strategic mineral, energy and protein supplements. In South Africa, most cattle and sheep are kept and bred on large grazing systems all over the country. The majority of lambs and older sheep are fattened and marketed directly from these grazing systems, while a small proportion of lambs are fattened for short periods in feedlots to achieve more consistent carcass weights and quality. By contrast, weaned cattle are generally sold at liveweights varying between $160 \mathrm{~kg}$ and $220 \mathrm{~kg}$, in order to reduce stocking rates and improve the management of grazing systems. Few farmers in South Africa retain weaners to the age of 18 months or older on grazing systems with varying amounts of concentrate feeding to produce an acceptable carcass for the South African market.

About $70 \%$ of all weaned calves are sold to fatten at cattle feedlots before slaughter at target weights of about $400-450 \mathrm{~kg}$ to yield carcasses of about $220-250 \mathrm{~kg}$ (Webb, 2013). This is more easily achieved by feeding different proportions of concentrate diets, with or without feed additives and growth promotants that are approved for use in food-producing animals. At this point the cattle are relatively young (12 - 16 months of age), while older animals are rarely produced from the feedlot system (Frylinck et al., 2013).

In southern Africa, environmental and economic conditions significantly influence production systems and often result in shifts from pasture-based (extensive) to conventional or concentrate-based finishing (intensive) before marketing. Feedlots contract or buy young weaned cattle from grazing systems, while beef cattle farmers specialize more on the multiplication of animals based on large numbers of cows and calves kept on pasture or natural grazing. A more recent trend is that feedlots buy weaned calves at liveweights of about $150 \mathrm{~kg}$ for grass feeding with small amounts of concentrate supplementation (backgrounding) to ensure better adaptation and subsequent feedlot performance (Webb, personal observation).

\section{Growth promoting substances and production systems Use of antimicrobial drugs in livestock production}

Antimicrobial drugs, which include antibiotics such as tetracycline and penicillin, are substances that prevent or kill the growth of harmful bacteria, fungi or protozoa, which is vital in the treatment of infections and diseases in human beings and animals. The use of antibiotics in animal agriculture represents one of the most contentious issues that this industry is facing. Antibiotics have been broadly used in one of four ways in food-producing animals, namely therapeutic use to treat infections and diseases; metaphylaxis or short-term treatment and prevention of diseases; prophylaxis or long-term use to prevent diseases and conditions in intensively kept animals that have a high risk of disease or infections; and lastly sub-therapeutic use to enhance growth performance and improve feed efficiency (Mathew et al., 2007).

Growth-promoting effects of antimicrobials were discovered in the early 1900s in the USA and their use initially gained popularity in the 1950s in pig and poultry production systems. A meta-analysis of about two dozen studies was conducted by Wileman et al. (2009), and they concluded that conventional feeding systems that employ endectocides, metaphylaxis technologies and hormonal growth implants are beneficial in terms of animal growth, average daily gains, feed conversion efficiency and dry matter intake. In the same study, it was calculated that morbidity was $29 \%$ in conventional feeding systems with antimicrobials compared with 55\% in systems without any preventative treatment. Mortality rates were significantly lower in conventional systems with metaphylaxis (1.8\%) compared with organic or natural systems (3.8\%). Improvements in growth and feed efficiency were also observed in intensively fed beef cattle treated with sub-therapeutic doses of antimicrobials. These antimicrobials were referred to as 'antibiotic growth promoters' or AGPs, and European countries raised concern about the use of these substances soon after their adoption (Cogliani et al., 2011). Swedish farmers requested a ban on AGPs in 1986 because of a drop 
in consumer confidence in animal products owing to the excessive use of these substances for growth promotion.

In the 1960s, scientists became aware of antibiotic resistance of bacteria associated with the use of antimicrobials in human medicine and food-producing animals (Mathew et al., 2007). The debate about the misuse of antimicrobials and antimicrobial resistance continued for almost 40 years before the subtherapeutic use of antimicrobials in food-producing animals was banned by the European Union (EU) in January 2006. South Africa followed suit and enforced the ban on the sub-therapeutic use of antimicrobials in food-producing animals (Henton et al., 2011). Although the use of antimicrobials remains challenging, the controversy about its misuse in animals has diminished because the use of these substances is very strictly regulated. In the USA, a partial ban on the agricultural use of certain tetracycline and penicillin drugs in animals was announced in 2012 to prevent these drugs from losing their efficacy in the treatment of diseases and conditions in human beings.

\section{Hormonal growth implants and feed supplements}

The beef industry (excluding the EU) uses hormonal growth implants such as anabolic steroids (natural and synthetic androgens, oestrogens and progestins) and feed additives such as beta-adrenergic agonists (zilpaterol hydrochloride in cattle and ractopaminehydrochloride in pigs) to enhance growth during the fattening phase. These practices have gained popularity owing to the significant improvements in growth and feed efficiency of treated cattle and improvements in carcass composition (Fiems, 1987; Johnson et al., 2013). The use of anabolic steroids caused a furore in the 1970s. This resulted in the withdrawal of diethylstilbestrol (DES), a product that had been used for more than 20 years in the USA before it was banned for use in food-producing animals in 1979. New anabolic steroids that are now used in cattle and sheep are subject to severe scrutiny and testing. These include oestradiol E2, oestradiol benzoate, zeranol, trenbolone acetate and testosterone propionate. Scientific data show that these growth promotants are safe for use in livestock, and products from animals treated with these growth implants pose no health or environmental risks, because the concentrations in implanted animals are marginally higher than nonimplanted counterparts and the estrogenic content is often lower than non-meat items such as milk and milk products, as well as certain legumes and vegetables (Preston, 1997; Johnson et al., 2013).

Beta-adrenergic agonists are particularly useful feed additives because they repartition nutrients towards protein accretion rather than fat synthesis (Mersmann, 1998). Overall feedlot performance of cattle is improved significantly after relatively short treatment periods (30 days) and use of low concentrations ( $<10 \mathrm{mg} / \mathrm{kg}$ in feed) of these feed additives (Montgomery et al., 2009). In South Africa, the use of these growth-promoting molecules in livestock is under strict control and has to adhere to compulsory withdrawal periods (Farm Feeds, Agricultural Remedies and Stock Remedies Act, No 36 of 1947). The effect of supplementing feedlot diets with a beta-agonist during the last 25 to 30 days of the fattening period is leaner carcasses with a better conformation, which complies with consumer demands for leaner meat (Webb \& O'Neill, 2008). There is also evidence to show that the fat content and fatty acid composition of meat from beta-agonist treated cattle may be more acceptable from a human health perspective (Webb \& Casey, 1995).

On the other hand, meat from animals fed beta-adrenergic agonists is less tender (Dunshea et al., 2005; O’Neill et al., 2010; Strydom et al., 2011). Although vitamin $\mathrm{D}_{3}$ supplementation in the feed for the last 3 to 5 days prior to slaughter was proposed as a way to improve meat tenderness of zilpaterol hydrochloride treated feedlot cattle, the benefits are negligible (Hope-Jones et al., 2012). Post-mortem electrical stimulation and ageing of carcasses for 7 to 14 days improves meat quality but does not completely overcome the adverse effects of beta-agonist treatment on meat tenderness in feedlot cattle (Hope-Jones et al., 2010; Strydom et al., 2011). The cost-benefit of ageing beef in South Africa for extended periods limits the practical application of this practice to selected retailers and niche markets.

\section{Beef and mutton from different production systems}

There is currently a lot of debate about the quality of animal products from different production systems, especially meat from livestock fed in feedlots versus grass fattening. Much of this debate is spurred by the industries involved and is fast becoming one of the cornerstones of branding meat products. Unfortunately, this debate is often taken too far, and may detract from the generally good perceptions consumers have of animal products. However, research indicates that production systems affect meat quality (Frylinck et al., 2013), owing to differences in growth rates, age at slaughter, carcass fat and fatty acid 
content, meat and fat colour, as well as dietary effects on muscle energy status, which affects the conversion of muscle to meat and subsequent meat quality.

\section{Effect of production system on meat colour}

One of the most pronounced differences in beef from pasture versus concentrate-fed cattle is meat colour. A number of reports confirm that pasture-fed cattle have darker meat (Therkildsen et al., 1998; Bruce et al., 2004; Mancini \& Hunt, 2005). In addition, Priolo et al. (2001) examined 35 experiments in which the effect of pasture versus concentrate feeding on meat colour was assessed by objective and subjective methods in the same meat cuts. The results confirm that dietary components and in particular grass feeding affect meat colour and flavour in cattle and sheep. Meat from beef and sheep raised on pasture or extensive grazing is generally darker than meat from ruminants fed concentrates, which was confirmed by both objective (meat lightness) and subjective (meat brightness) measurements (Priolo et al., 2001; Priolo et al., 2002). Meat from pasture-fed animals is about $10 \%$ less bright than that from concentrate-fed animals.

Differences in colour are owing to different factors, but animal age, muscle energy status of the specific cut and inherent meat and fat colour appear to be the major factors. Priolo et al. (2001) investigated the possible effect of carcass fat cover on meat colour, owing to the observation that fatter carcasses have a slower cooling rate and rigor mortis is achieved at a higher carcass temperature. These cause a faster $\mathrm{pH}$ decline and may explain differences in meat colour. However, the results show that even if carcasses from pasture-fed animals contained more fat, the meat colour was still darker. In sheep, the differences in colour of meat from pasture and concentrate-fed lambs tended to disappear over time on display ( $>24$ hours postmortem) (Priolo et al., 2002).

Consumers are perceptive about meat colour, which explains about $15 \%$ of the variation in consumer acceptance of meat (Smith et al., 2000). Meat colour is not an important eating characteristic, but it is a major factor in the consumer's choice. Most consumers prefer bright, cherry-red meat, while pale or dark meat is less acceptable (Killinger et al., 2004). A condition known as dark, firm and dry meat (DFD) has been described in cattle, which is the result of pre-slaughter stress or low muscle energy status pre-slaughter (Tarrant, 1989), and this condition was also observed in South Africa (Viljoen et al., 2002). The DFD condition is often seen in pasture-fed cattle or poorly conditioned cattle (Therkildsen et al., 1998; Nuernberg et al., 2005; Frylink et al., 2013), especially during excessive climatic variations (Viljoen et al., 2002).

The results of research in South Africa on the effects of pasture versus concentrate feeding show that if steers are slaughtered at the same age, the carcass weights of pasture-fed steers are lower than those from concentrate-fed steers (Frylink et al., 2013). If steers are raised on pastures to the same slaughter weight (ca. $400-450 \mathrm{~kg}$ ), they have a substantially longer growth period and are fed to an older age (about 36 months). Steers raised on pasture also had a significantly lower glycolytic potential and the $\mathrm{pH} /$ temperature decline rate of carcasses was slower than those from feedlot systems. This resulted in a higher incidence of DFD meat in carcasses of cattle fed on pastures, and the meat had higher shear force values and more variation in tenderness (Frylink et al., 2013). A higher shear force value of meat is indicative of lower meat tenderness. These researchers concluded that production system, diet and slaughter conditions influenced meat quality more than animal age. Typical feedlot diets with high-energy content increase the capacity for post-mortem glycolysis, which is more beneficial for the normal conversion of muscle to meat. By contrast, undernutrition or poorly conditioned animals have insufficient muscle glycogen reserves, which is a major cause of high ultimate carcass $\mathrm{pH}$.

It is well known that pasture-fed animals deposit more yellow pigments in their fat depots, especially if the pastures or hay is green and lush. Sheep fed lucerne hay deposited more carotenoid pigments (xanthophyll or lutein) in subcutaneous fat depots than those fed concentrate diets (Kruggel et al., 1982; Therkildsen et al, 1998). Also in Europe (France) where pastures are lush and green, researchers confirmed that fat from pasture-fed sheep was more yellow and harder than concentrate-fed animals (Priolo et al., 2002). Similar results were observed in sheep from local production systems (Webb et al., 1999), but since the quality of grazing differs more between seasons in South Africa, the effects of pigments in the grazing tend to be less significant in the dry months of the year. In fact, it became customary to market pasture-fed livestock in the dry season to reduce complaints about yellow discolouration of carcass fat.

As early as the 1960s consumer resistance was noted towards carcasses with non-icteric yellow fat (Hill, 1962), because of the perception that yellow fat is indicative of old age or that it is from diseased animals, or in beef fat, it is from dairy-type carcasses (Webb et al., 1999). In New Zealand about 3.5\% to 7\% 
of sheep slaughtered contained yellow fat and this was not regarded a major problem at the time, but yellow discoloration of carcasses created major concern in Ireland. Fat quality is difficult to define, because the perceived quality of fat varies significantly between consumers from different socio-demographic backgrounds, in terms of their preference for fat quantity, colour, consistency and chemical composition in different species of livestock (Webb \& O’Neill, 2008). Generally, carcasses with yellow fat are preferred in Eastern countries, and Australia has exploited that market well, while yellow fat is not favoured in Western countries.

\section{Effect of production system on meat flavour}

Meat flavour is a relatively complex aspect of meat quality (Melton, 1990) and perceptions about meat flavour are influenced by previous experience and cultural background. More than 50 odour-active compounds have been identified that could possibly be linked to meat flavour (Priolo et al., 2001; 2004). Some of these flavour compounds are species specific, but diet or feeding system influences the presence and concentrations of these compounds. The typical pasture flavour in lamb is owing to the presence of branched-chain fatty acids and 3-methylindole (skatole), as well as products of oxidation of linolenic acid. In cattle, the flavour components differ from those in sheep since 3-methylindole is not important. Lamb and beef flavour is also influenced by carcass fat content (Melton, 1990; Bosman et al., 2000; Priolo et al., 2001) and fatty acids (Webb et al., 1994a; b). In most countries, meat flavour of intensively fed livestock is preferred to pasture-fed animals. This is true of the USA in particular, where the majority of studies on meat flavour show conclusively that grain-fed beef is preferred to grass-fed beef (Priolo et al., 2001).

In lamb, off-flavours in meat from grass-fed animals were detected that were associated with a high ultimate carcass pH (Young et al., 1993). These off-flavours were particularly noticeable when the diet contained condensed tannins, which are more typical of pastures. According to Priolo et al. (2001), at least 10 of the flavour components of meat are $\mathrm{pH}$ sensitive which may be affected by high ultimate carcass $\mathrm{pH}$ values, and data indicate that it may take up to three months to eliminate the typical grass flavour in lamb. A more important indicator of grass feeding is 2,3-octanedione, which is about 25 times higher in meat from grass-fed animals than concentrate-fed animals, and may explain some of the flavour differences between grass-fed and concentrate-fed animals. There are some reports on the presence of a higher concentration of skatole (3-methylindole) in pasture-fed lambs than concentrate-fed lambs (Young et al., 2003), but the differences seem to be small in older animals.

\section{Effect of production system on fat content and fatty acid composition}

Animal production systems and feeding methods influence carcass fat content and fatty acid composition (Webb \& O'Neill, 2008), and fats and fatty acids influence meat quality (Wood et al., 2003). The influence of animal fats on human health has become particularly important, and current research is directed at manipulating the fatty acid content of meat animals in order to increase n-3, essential fatty acids and conjugated linoleic acid (CLA) in animal fats (Enser et al., 1998; Raes et al., 2004; Scollan et al., 2006). Ruminant species serve as excellent dietary sources of CLAs, which are synthesized by microbial isomerization of dietary linoleic acid in the rumen and in the body. It has been indicated that CLAs have favourable health properties in humans, by reducing the risk of cancer, atherosclerosis and diabetes, and improving immune function (Rainer \& Heiss, 2004). Pasture feeding has gained popularity owing to the positive effects on the fatty acid composition of meat of various species, albeit at the expense of higher growth performance (Webb \& O’Neill, 2008).

Finishing ruminants on pasture can decrease the n- $6: n-3$ ratio to a value of less than 2, while this ratio is in excess of 6 in concentrate-fed ruminants (Enser et al., 1998). Beef from low-input pasture systems has a low intramuscular fat and cholesterol content (Muchenje et al., 2009). Wood et al. (2008) also indicated that grass feeding has beneficial effects on the $n-3$ fatty acids, notably eicosapentaenoic acid (EPA; C20:5n-3) and docasahexaenoic acid (DHA; C22:6n-3). The fatty acid composition of Argentinian beef is also noticeably affected by diet (Descalzo et al., 2005), where grain-fed beef had a higher intramuscular fat and cholesterol content than meat from pasture raised cattle. The fatty acid composition of beef from pasture-fed cattle was more favourable with higher proportions of linolenic acid, less linoleic acid and higher proportions of polyunsaturated fatty acids than beef from grain-fed animals (Descalzo et al., 2005). Similar results were observed in lambs, where pasture feeding increased the proportions of linolenic acid, conjugated C18:2 cis-9, trans-11 and C22:5, compared with concentrate-fed animals (Aurousseau et al., 2007). Unfortunately, dietary 
manipulation of fatty acids in ruminants has a marginal effect on tissue content, since the concentrations of many of these beneficial fatty acids are small. For example, c9t11-conjugated linoleic acid in beef and lamb varies between $0.2 \mathrm{mg} / 100 \mathrm{~g}$ and $1 \mathrm{mg} / 100 \mathrm{~g}$ of total fatty acids (Raes et al., 2004). The results of Casey \& Webb (1995) also indicated that lambs fed concentrates may contain marginally higher proportions of transfatty acids than those fed higher proportions of hay, but again the concentrations of these fatty acids in beef and lamb are small and the dietary significance is uncertain.

\section{Effects of production system on meat tenderness}

Meat tenderness is regarded as one of the most critical quality parameters of meats. Consensus about the effect of pasture versus concentrate feeding on meat tenderness is clearly in favour of concentrate-fed animals. Meat from pasture-fed animals was less tender, and these results were confirmed in lamb (Priolo et al., 2002; Resconi et al., 2009) and beef (Nuernberg et al., 2005; Resconi et al., 2010; Frylinck et al., 2013) in various countries, including countries in the European Union, USA, and South Africa. Oliver et al. (2006) highlighted the importance of market segmentation, and showed that consumers in the same country do not necessarily prefer the same products. Nevertheless, British and German consumers have a strong preference for beef with acceptable tenderness and flavour, which is different from that of Spanish consumers.

One of the first conclusive studies on the effect of production system on meat quality was conducted in Denmark by Vestergaard et al. (2000), who reported lower sensory scores for tenderness, taste and juiciness of pasture-fed bulls than intensively fed bulls. Nuernberg et al.'s (2005) research is well cited and showed that meat from pasture-fed bulls was less tender than that from concentrate-fed bulls. These results were confirmed with sensory testing by a trained sensory panel and instrumental toughness assessment. The results correspond with those of other studies (Larick et al., 1987), where tenderness of meat was tested by a Warner Bratzler shear force apparatus. One possible explanation that was provided by the researchers for the higher shear force values of pasture-fed beef is that the grass-fed bulls were older at the point of slaughter. This finding is in agreement with the results of Resconi et al. (2010), who found that steers with the highest growth rates produced more tender meat. Razminowicz et al.'s (2006) results in Switzerland show no difference in texture between grass-fed and conventionally fed cattle, although pasture-fed beef exhibited a rather intense colour. In lambs there are similarly convincing results that confirm the beneficial effects of concentrate feeding on tenderness, but with the added benefits of reducing the occurrence of off-flavours (rancid, strange, acid) and odours in lamb (Resconi et al., 2009).

\section{Carcass composition and consistency of meat quality}

Grass feeding has beneficial effects on the shelf life of meat products owing to the presence of antioxidants such as vitamin E (Wood et al., 2003), which may prevent autoxidation of poly-unsaturated fatty acids (PUFA) and improve visual carcass attributes. Haem compounds in all red meats with a low lipid : haem ratio can stabilize peroxides of free radicals and exert an antioxidant effect (Casey et al., 2003). Nevertheless, the beneficial effects of antioxidants are exploited in commercial feedlot operations, and many now use dietary vitamin E supplementation to improve the shelf life and keeping qualities of lamb and beef (Webb et al., 2008). Argentinian beef from grain-fed systems has been supplemented with vitamin $\mathrm{E}$ at 500 IU/animal/day and this has improved the antioxidant status of meat, but not to the same extent as pasture-fed beef (Descalzo et al., 2005).

An attribute that is of huge importance is carcass composition (muscle and fat content). Concentrate feeding has significant benefits, because the fattening process is highly regulated to a predetermined endpoint, which yields carcasses with extremely consistent composition and quality with similar classification scores or grades. This addresses one of the major problems in the meat industry, namely producing a more consistent product. This is achievable in pasture-based systems, but will require better management and moderate concentrate supplementation. In fact, studies in Ireland indicate that pasture-fed beef with moderate concentrate supplementation produces the most acceptable and tender meat (French et al., 2000).

\section{Conclusions}

The ruminant livestock sector uses various combinations of pasture-based and conventional or concentrate-based feeding systems to supply the increasing demands for products of animal origin. Production efficiency and quality of animal products are influenced by production systems, but these differ, 
depending on environmental and climatic conditions and resources. Production systems affect the extrinsic and intrinsic aspects of animal products from cattle and small stock, with noticeable effects on carcass and meat quality.

Concentrate feeding generally yields a more consistent carcass composition than pasture-fed animals, which addresses the necessity for more consistent meat quality. Intrinsic aspects of animal products that are affected include carcass composition and conformation, carcass fat content and colour, meat composition, colour, tenderness and flavour. Meat from pasture-fed animals is darker and less tender, and the carcasses may contain more yellow pigment. In many countries, the meat flavour of intensively fed livestock is preferred to pasture-fed animals. Meat from pasture-fed animals has a stronger flavour and may contain offflavours, but certain consumers prefer the more intense pasture flavour. Pasture feeding has beneficial effects on the n-3 fatty acids, notably EPA (C20:5n-3) and DHA (C22:6n-3). Beef and lamb from pasture-fed animals are generally less tender, but shelf life is better, owing to the presence of antioxidants such as vitamin E.

\section{References}

Allen, H.K., Levine, U.Y., Looft, T., Bandrick, M. \& Casey, T.A., 2013. Treatment, promotion, commotion: antibiotic alternatives in food-producing animals. Trends Microb. 21 (3), 114-119.

Aurousseau, B., Bauchart, D., Calichon, E., Micol, D. \& Priolo, A., 2004.Effect of grass or concentrate feeding systems and rate of growth on triglyceride and phospholipid and fatty acids in the $\mathrm{M}$. longissimus thoracis of lambs. Meat Sci. 66, 531-541.

Bruce, H.L., Stark. J.L. \& Beilken, S.L., 2004. The effects of finishing diet and post mortem ageing on the eating quality of the M. longissimus thoracis of electrically stimulated Brahman steer carcasses. Meat Sci. 67, 261-268.

Casey, N.H., Van Niekerk, W.A. \& Webb, E.C., 2003. Goat Meat. Encyclopaedia of Food Sciences and Nutrition. pp. 2937-2944.

Cogliani, C., Goossens, H. \& Greko, C., 2011. Restricting antimicrobial use in food animals: Lessons from Europe. Microbe 6, 274-279.

Delgado, C., Rosegrant, M., Steinfeld, H., Elui, S. \& Courboyi, C., 1999. Livestock to 2020 - The Next Food Revolution, Food and Agriculture and the Environment. Discussion Paper 28, IFPRI, Washington, D.C., USA.

Descalzo, A.M., Insani, E.M., Biolatto, A., Sancho, A.M., Garcia, P.T., Pensel, N.A. \& Josifovich, J.A., 2005. Influence of pasture or grain-based diets supplemented with vitamin E on antioxidant / oxidative balance of Argentine beef. Meat Sci. 70, 35-44.

Dunshea, F.R., D’Souza, D.N., Pethick, D.W., Harper, G.S. \& Warner, R.D., 2005. Effects of dietary factors and other metabolic modifiers on quality and nutritional value of meat. Meat Sci. 71, 8-38.

Enser, M., Hallett, K.G., Hewett, B., Fursey, G.A.J., Wood, J.D. \& Harrington, G., 1998. Fatty acid content and composition of UK beef and lamb muscle in relation to production system and implications for human nutrition. Meat Sci. 49, 329-341.

Fiems, L.O., 1987. Effect of beta-adrenergic agonists in animal production and their mode of action. Ann. Zootech. 36, 271-290.

Frazer, D., 2005. Animal welfare and the intensification of animal production, an alternative interpretation. Food and Agriculture Organisation of the United Nations, Rome, 2005.

French, P., O’Riordan, E.G., Monahan, F.J., Caffrey, P.J., Vidal, M., Mooney, M.T., Troy, D.J. \& Moloney, A.P., 2000. Meat quality of steers finished on autumn grass, grass silage or concentrate-based diets. Meat Sci. 56, 173-180.

Frylinck, L., Strydom, P.E., Webb, E.C. \& Du Toit, E., 2013. Effect of South African beef production systems on post-mortem muscle energy status and meat quality. Meat Sci. 93, 827-837.

Green, R.M., Qureshi, M.A., Long, J.A., Burfening, P.J. \& Hamernik, D.L., 2007. Identifying the future needs for long-term USDA efforts in agricultural animal genomics. Int. J. Biol. Sci. 3, 185-191.

Henton, M.M., Eagar, H.A., Swan, G.E. \& Van Vuuren, M., 2011. Antibiotic management and resistance in livestock production. S. Afr. Med. J. 101, 1-8.

Hill, F., 1962. Yellow fat in sheep, Irish J. Agric. Res. 1, 84. 
Hope-Jones, M., Strydom, P.E., Frylinck, L. \& Webb, E.C., 2010. The efficiency of electrical stimulation to counteract the negative effects of $\beta$-agonists on meat tenderness of feedlot cattle. Meat Sci. 86, 699-705.

Hope-Jones, M., Strydom, P.E., Frylinck, L. \& Webb, E.C., 2012. Effect of dietary beta-agonist treatment, vitamin $\mathrm{D}_{3}$ supplementation and electrical stimulation of carcasses on colour and drip loss of steaks from feedlot steers. Meat Sci. 90, 607-612.

Ilea, R.C., 2009. Intensive livestock farming: Global trends, increased environmental concerns, and ethical solutions. J. Agr. Environ. Ethic. 22, 153-167.

Johnson, B.J., Ribeiro, F.J.B. \& Beckett, J.L., 2013. Application of growth technologies in enhancing food security and sustainability. Anim. Frontiers 3, 8-13.

Killinger, K.M., Calkins, W.J., Umberger, W.J., Feuz, D.M. \& Eskridge, K.M., 2004. Consumer visual preferences and value for beef steaks differing in marbling level and color. J. Anim. Sci. 82, 3288-3293.

Kruggel, W.G., Field, R.A., Miller, G.J., Horton, K.M. \& Bushboom, J.R., 1982. Influence of sex and diet on lutein in lamb fat. J. Anim. Sci. 34, 970.

Larick, D.K., Hendrick, H.B., Bailey, M.E., Williams, J.E., Hancock, D.L., Garner, G.B. \& Morrow, R.E., 1987. Flavor constituents of beef as influenced by forage-and grain-feeding, J. Food Sci. 52, 245-251.

Mancini, R.A. \& Hunt, M.L., 2005. Current research in meat colour. Meat Sci. 71, 100-121.

Mathew, A.G., Cissell, R. \& Liamthong, S., 2007. Antibiotic resistance in bacteria associated with food animals: A United States perspective of livestock production. Food Born Path. Dis. 4 (2), 115-133.

Melton, S.L., 1990. Effects of feeds on flavour of red meat: A Review. J. Anim. Sci. 68, 4421-4435.

Mersmann, H.J., 1998. Overview of the effects of beta-adrenergic receptor agonists on animal growth including mechanism of action. J. Anim. Sci. 76, 160-172.

Montgomery, J.L., Krehbiel, C.R., Cranston, J.J., Yates, D.A., Hutcheson, J.P., Nichols, W.T., Streeter, M.N., Bechtol, D.T., Johnson, E. \& TerHune, T., 2009. Dietary zilpaterol hydrochloride. I. Feedlot performance and carcass traits of steers and heifers. J. Anim. Sci. 87, 1374-1383.

Muchenje, V., Hugo, A., Dzama, K., Chimonyo, M., Strydom, P.E. \& Raats, J.G., 2009. Cholesterol levels and fatty acid profiles of beef from three cattle breeds raised on natural pasture. J. Food Comp. Anal., 22, 354-358.

Muir, P.D., Beaker, J.M. \& Brown, M.D., 1998. Effects of forage- and grain-based feeding systems on beef quality: A review. N. Z. J. Agric. Res. 41, 623-635.

Oliver, M.A., Nute, G.R., Font iFurnols, M., San Julian, R., Campo, M.M., Sanudo, C., Caneque, V., Guerrero, L., Alvarez, I., Diaz, M.T., Branscheid, W., Wicke, M. \& Montossi, F., 2006. Eating quality of beef, from different production systems, assessed by German, Spanish and British consumers. Meat Sci. 74, 435-442.

Nuernberg, K., Dannenberger, D., Nuernberg, G., Ender, K., Voigt, J., Scollan, N.D., Wood, J.D., Nute, G.R. \& Richardson, R.I., 2005. Effect of grass-based and a concentrate feeding system on meat quality characteristics and fatty acid composition of longissimus muscle in different cattle breeds. Livest. Prod. Sci. 94, 137-147.

O’Neill, H.A., Casey, N.H. \& Webb, E.C., 2010. Interactive effect of feed protein level and zilpaterol hydrochloride on feedlot performance and meat quality of steers. S. Afr. J. Anim. Sci. 40, 185-189.

Pica-Ciamarra, U. \& Otte, J., 2009. The 'Livestock Revolution': Rhetoric and Reality, Pro-Poor Livestock Policy Initiative, A Living from Livestock. RPPLPI Research Report RR Nr. 09-05, November 2009. www.fao.org/ag/pplpi.html.

Preston, R.L., 1997. Rationale for the safety of implants, impact of implants on performance and carcass value of beef cattle. Oklahoma Agricultural Experiment Station, Oklahoma State University, USA. pp. 199-203.

Priolo, A., Micol, D. \& Agabriel, J., 2001. Effects of grass feeding systems on ruminant meat colour and flavour. Anim. Res. 50, 185-200.

Priolo, A., Micol, D., Agabriel, J., Prache, S. \& Dransfield, E., 2002. Effect of grass or concentrate feeding system on lamb carcass and meat quality. Meat Sci. 62, 179-185.

Priolo, A., Cornu, A., Prache, S., Krogmann, M., Kondjoyan, N., Micol, D. \& Berdague, J-L., 2004. Fat volatiles tracers of grass feeding in sheep. Meat Sci. 66, 475-481. 
Raes, K., De Smet, S. \& Demeyer, D., 2004. Effect of dietary fatty acids on incorporation of long chain polyunsaturated fatty acids and conjugated linoleic acid in lamb, beef and pork meat: A review. Anim. Feed Sci.Technol. 113, 199-221.

Rainer, L. \& Heiss, C.J., 2004. Conjugated linoleic acid: Health implications and effects on body composition. J. Am. Diet. Ass. 6, 963-968.

Razminowicz, R.H., Kreuzer, M. \& Scheeder, M.R.L., 2006. Quality of beef from two grass-based production systems in comparison with conventional beef. Meat Sci. 73, 351-361.

Roughgarden, J., 1979. Theory of Population Genetics and Evolutionary Ecology: An Introduction. Macmillan, New York.

Resconi, V.C., Campo, M.M., Font i Funols, M., Montossi, F. \& Sanudo, C., 2009. Sensory evaluation of castrated lambs finished on different proportions of pasture and concentrate feeding systems. Meat Sci. 83, 31-37.

Resconi, V.C., Campo, M.M., Font i Furnols, M., Montossi, F. \& Sanudo, C., 2010. Sensory quality of beef from different finishing diets. Meat Sci. 86, 865-869.

Scollan, N., Hocquette, J-F., Nuernberg, K., Dannenberger, D., Richardson, I. \& Moloney, A., 2006. Innovations in beef production systems that enhance the nutritional and health value of beef lipids and their relationship with meat quality. Meat Sci. 74, 17-33.

Smith, G.C., Belk, K.E., Sofos, J.N., Tatum, J.D. \& Williams, S.N., 2000. Economic implications of improved colour stability in beef. In: Antioxidants in muscle foods: Nutritional strategies to improve quality. Eds: Decker, E.A., Faustman, C. \& Lopez-Bote, C.J., New York: Wiley Interscience. pp. 397-426.

Steinfeld, H., 2004. The livestock revolution - a global veterinary mission. Vet. Parasitol. 125, 19-41.

Steinfeld, H., Gerber, P., Wassenaar, T., Castel, V., Rosales, M. \& De Haan, C., 2006. Livestock’s Long Shadow. Food and Agriculture Organisation of the United Nations (FAO), http://www.fao.org/docrep/010/a0701e/a0701e00.htm.

Strydom, P.E., Hope-Jones, M., Frylinck, L. \& Webb, E.C., 2011. The effects of a beta-agonist treatment, vitamin $\mathrm{D}_{3}$ supplementation and electrical stimulation on meat quality of feedlot steers. Meat Sci. 89, 462-468.

Tarrant, P.V., 1989. Animal behaviour and environment in the dark cutting condition. In: Dark Cutting in Cattle and Sheep. Eds: Fabiansson, S.U., Shorthose, W.R. \& Warner, R.D., Sydney: Australian Meat and Livestock Research and Development Corporation. pp. 8-18.

Therkildsen, M., Vestergaard, M., Jensen, L.R., Andersen, H.R. \& Sejrnsen, K., 1998. Effects of feeding level, grazing and finishing on growth and carcass quality of young Friesian bulls. Acta Agric. Scan. (A) - Anim. Sci. 48 (4), 193-201.

Vestergaard, M., Therkildsen, M., Henckel, P., Jensen, L.R., Andersen, H.R. \& Sejrsen, K., 2000. Influence of feeding intensity, grazing and finishing feeding on meat and eating quality of young bulls and the relationship between muscle fibre characteristics, fibre fragmentation and meat tenderness. Meat Sci. 54, 187-195.

Viljoen, H.F., De Kock, H.L. \& Webb, E.C., 2002. Consumer acceptability of dark, firm and dry (DFD) and normal $\mathrm{pH}$ beef steaks. Meat Sci. 61, 181-185.

Webb, E.C., 2013. The ethics of meat production and quality - A South African perspective. S. Afr. J. Anim. Sci. 43 (5), S2-S10.

Webb, E.C. \& Casey, N.H., 1995. Fatty acids in carcass fat of steers treated with a ß-adrenergic agonist feed additive and a trenbolone acetate + oestradiol - 17ß implant. Meat Sci. 41, 69-76

Webb, E.C. \& O’Neill, H.A., 2008. The animal fat paradox and meat quality. Meat Sci. 80, 28-36.

Webb, E.C. \& Casey, N.H., 2010. Physiological limits to growth and the related effects on meat quality. Livest. Sci. 130, 33-40.

Webb, E.C., Bosman, M.J.C. \& Casey, N.H., 1994a. Dietary influences on subcutaneous fatty acid profiles and sensory characteristics in Dorper and SA Mutton Merino wethers. S. Afr. J. Food Sci. Nutr. 6 (2), 45-50.

Webb, E.C., Casey, N.H. \& Van Niekerk, W.A., 1994b. Fatty acids in the subcutaneous adipose tissue of intensively fed SA Mutton Merino and Dorper wethers. Meat Sci. 38, 123-131.

Wood, J.D., Richardson, R.I., Nute, G.R., Fisher, A.V., Campo, M.M., Kasapidou, E., Sheard, P.R. \& Enser, M., 2003. Effects of fatty acids on meat quality: a review. Meat Sci. 66, 21-32. 
Wood, J.D., Enser, M., Fisher, A.V., Nute, G.R., Sheard, P.R., Richardson, R.I., Hughes, S.I. \& Whittington, F.M., 2008. Fat deposition, fatty acid composition and meat quality: A review. Meat Sci. 78, 343-358.

Wileman, B.W., Thomson, D.U., Reinhardt, C.D. \& Renter, D.G., 2009. Analysis of modern technologies used in beef cattle production: Conventional beef production versus nonconventional production using meta-analysis. J. Anim. Sci. 87, 3418-3426.

Young, O.A., Reid, D.H. \& Scales, G.H., 1993.Effect of breed and ultimate pH on the odour and flavour of sheep meat. N. Z. J. Agric. Res. 36, 363-370.

Young, O.A., Lane, G.A., Priolo, A. \& Fraser, K., 2003. Pastoral and species flavour in lambs raised on pasture, lucerne or maize. J. Sci. Food Agric. 83, 93-104. 